\title{
Multi-Level Governance as a Constitutional Principle in the Legal System of the European Union
}

\section{Carlo Panara*}

\author{
UDK: $\quad 35.071 .5(4) \mathrm{EU}$ \\ $341.176(4) \mathrm{EU}$ \\ 342.4:061.1(4)EU \\ Original scientific paper / izvorni znanstveni rad \\ Received / primljeno: 6. 6. 2016. \\ Accepted / prihvaćeno: 16. 12. 2016
}

The article examines the notion of multi-level governance (MLG) in the EU as developed by the Committee of the Regions in the 2009 White Paper on MLG. It analyses MLG from a legal perspective to identify its legal basis. The paper sketches out the nature of MLG as a procedural principle in the EU legal system and identifies four functions of MLG: shaping the EU as a polity, shaping future developments in EU law, shaping the behaviour of political actors within the EU, and shaping the interpretation of EU law by the CJEU. It concludes that MLG as a legal principle shall guide the judicial interpretation and application of EU law, particularly in relation to the enforcement of the principle of subsidiarity, of participation rights of local and

* Carlo Panara, PhD, Reader in EU Law and Comparative Public Law, John Moores University, Liverpool, United Kingdom (predavač Europskog i komparativnog javnog prava Sveučilišta John Moores u Liverpoolu, Ujedinjeno Kraljevstvo, e-mail: C.Panara@ljmu. ac.uk). 
regional authorities, and of the locus standi of local and regional authorities in direct challenges to $\mathrm{EU}$ acts in Union courts.

Keywords: multi-level governance, local self-government, regional self-government, EU legal system

\section{Introduction}

The article ${ }^{1}$ will examine the notion of multi-level governance (MLG) in the EU. This notion, originally created by political scholars to understand and explain the functioning and particularly the decision-making processes of the EU, has subsequently become a normative and, more recently, a legal concept. Whilst the normative notion of MLG has been persuasively sketched out by political scholars (Piattoni, 2010; Stephenson, 2013), and more recently also by legal scholars (Vandenbruwaene, 2014), MLG as a legal notion requires further analysis.

At a very general level, MLG indicates the dispersion of authoritative decision-making across multiple players at different territorial levels within the EU (Marks \& Hooghe, 2001, p. XI). More specifically, MLG in the context of the EU can be used in relation to different phenomena, albeit linked to one another. These include the following:

1. A federalism-like system in the EU or at the national level with various tiers of government (European, national, regional, or local): Type 1 MLG (Marks \& Hooghe, 2004, pp. 17-20; Piattoni, 2010, pp. 246247)

2. Governance based on special-purpose agencies: Type 2 MLG (Marks \& Hooghe, 2001, pp. 20-22)

3. Public-private partnerships in the context of the EU Regional Policy (Marks, 1992, p. 191; Bache, 2004, p. 165)

4. Negotiation of policy by private and public players at the national and EU level (Schmitter \& Kim, 2005, p. 5)

The Type 1 vision of MLG implies a dispersion of authority to jurisdictions or authorities at a number of territorial levels. These jurisdictions or

${ }^{1}$ This article is a further development of my earlier study The Sub-national Dimension of the EU: A Legal Study of Multilevel Governance (Springer, 2015). I would like to thank the anonymous referees of this article for their helpful comments. 
authorities - international, national, regional, meso, or local - are "general-purpose" in that they bundle together multiple functions, policy responsibilities, and in many instances, like in the EU, a court system and representative institutions (Marks \& Hooghe, 2004, pp. 16-20; Hooghe \& Marks, 2010, pp. 17-20). Hooghe and Marks suggest that in this form of governance every citizen is located in a Russian Doll set of nested jurisdictions, where in principle there is one and only one relevant jurisdiction at any particular territorial scale (Marks \& Hooghe, 2004, p. 16; Hooghe $\&$ Marks, 2010, p. 17). These jurisdictions are intended to be, and usually are, stable over a relatively long period (years or even decades), even though the allocation of policy responsibilities across levels might be flexible. The archetype of Type 1 MLG is federalism, which is concerned with the allocation and sharing of powers among territorial jurisdictions (Hooghe \& Marks, 2010, p. 18; Marks \& Hooghe, 2004, p. 17).

Type 2 MLG comprises task-specific jurisdictions ("agencies") dealing with ad hoc issues such as transport, waste and recycling, water quality monitoring, and others. In Type 2 MLG there are intersecting memberships in that the agencies operate within a territory which is not neatly contained within the borders of a larger jurisdiction, and may therefore manage issues concerning citizens belonging to different territorial communities and states. The number of agencies is potentially unlimited and flexible, as in theory there could be as many agencies as are required by the various issues on the agenda, and the agency system could be reviewed as appropriate at any point in time (Marks \& Hooghe, 2004, pp. 20-22; Hooghe \& Marks, 2010, pp. 20-22).

The EU is the most advanced and complex example of Type 1 MLG beyond the national state, even though Hooghe and Marks highlight that certain areas of EU governance reflect a Type 2 MLG approach. These are, for example, the distinct governance systems or "pillars" for different policies, the multiplication of independent European agencies, and enhanced cooperation in certain fields such as monetary policy and border controls (Hooghe \& Marks, 2010, p. 23).

The focus of this study is the participation of regional and local authorities in EU decision-making processes (Skoutaris, 2012, p. 212; Panara, $2016 \mathrm{~b}$ ) in the context of Type 1 MLG. This choice finds justification in the prominent role of Type 1 MLG in the context of the EU (Hooghe \& Marks, 2010, p. 23). It also finds justification in the widely shared suggestion, coming especially from legal scholars, that the EU is a sui generis and supranational federation, which features many elements of a traditional federation (Schütze, 2012, pp. 77-79, even though he criticises the use 
of the adjective sui generis in relation to the EU; von Bogdandy 2009, p. 32). Finally, it finds justification in the prominence ascribed by important political documents of the EU, such as the White Paper on European Governance (2001) and the White Paper on MLG (2009), to concerns relating to Type 1 MLG.

According to a different narrative of MLG proposed by Piattoni (2009 and 2010, pp. 26-31), there are three different but combined "axes", i.e., three dimensions, of MLG. The first is "centre v. periphery", which indicates movements away from the unitary state towards decentralised systems of governance. The second is "domestic v. international", which indicates movements away from the national state towards increasingly structured modes of international cooperation and regulation, including the EU. The third is "state v. society", which portrays movements towards the increasing involvement of non-governmental organisations and civil society organisations in authoritative decision-making and policy implementation.

This study, which focuses on sub-national participation in EU processes, operates along the axes of "centre v. periphery" (including Type 1 MLG) and "domestic v. international" (including the shift of powers from the member states to the EU). The objective of this study is to look at MLG as a legal notion capable of reconciling these two movements into opposite directions - downwards towards decentralisation (axis 1) and upwards towards centralisation at EU level (axis 2) - whilst the third dimension of MLG ("state v. society") is not part of the current analysis.

Fo Following in the steps of earlier works (for example, Weatherill \& Bernitz, 2005; Mangiameli, 2006) and of EU primary law, this study will include both "local" and "regional authorities", i.e., the "sub-national" level of government within the EU. This approach should not be understood as a suggestion that there is a homogenous and undifferentiated sub-national level of government across the EU (Moore, 2008, p. 524). This methodology is consistent with EU primary law, which does not differentiate between the two types of sub-national authorities (the only exception to this lack of differentiation is Art. 6(1) of the Lisbon Subsidiarity Protocol, which envisages consultation with "regional parliaments with legislative powers").

The distinction between "local" and "regional" authorities is at times ambiguous at the national level as well. For example, all the French territorial communities share the same fundamental nature, irrespective of their level ("regions", "departments", or "communes"). In the UK, the concept of "local authority" is almost all-embracing in that it includes both small- 
er authorities (such as borough councils) and larger ones, such as combined authorities (e.g., Greater London Authority, Greater Manchester and Liverpool City Region). Furthermore, the concept of "region" might lead to speculation that a Spanish autonomous community is significantly different from a French region or a Belgian community. The only reliable distinction in this field is probably between regions with and without legislative powers. However, the legislative powers of regions also vary in various member states (cross-state asymmetry) and the constitutional standing of these regions varies accordingly. Whenever required by the rigour of this study, it will be clarified whether a conclusion applies to all sub-national authorities or only to some. Therefore, the approach chosen by this study - to include "local and regional authorities" in the analysis - will simplify the analysis without sacrificing its methodological rigour.

So far, the notion of MLG has been primarily employed by legal scholars in a descriptive manner, as a tool to illustrate the multi-layered nature of the EU, or as a paradigm to understand EU decision-making (for example, recently, Popelier et al., 2013; Cygan, 2013 and 2014; previously, Bernard, 2002 and Dubos, 2012). Some recent legal studies have explored MLG from a legal perspective, and more specifically, have attempted to evaluate the impact of MLG on constitutionalism in the EU (Popelier \& Vandenbruwaene, 2014; Panara, 2015, pp. 155-174), or construe MLG as a sui generis system of governance unique to the EU, which is different from federalism (Vandenbruwaene, 2014, pp. 235-237; Panara, 2015, pp. 166-168; contra see Schütze, 2009a, and Stein \& Turkewitsch, 2008).

Panara (2015) and Simonato (2016) have investigated the nature of MLG as a legal principle. Panara (2015, pp. 73-74) suggests that MLG is a "procedural principle" in that it commands a "method of governance" based on "participation and involvement of sub-national authorities in EU lawmaking and policymaking" (ibid. 73). Simonato (2016, pp. 221-223) construes MLG as a principle of coordination of the action of governmental actors at various levels within the EU. As a "descriptive principle" with a "heuristic function" (Simonato, 2016, p. 222), or as a "procedural principle" (Panara, 2015, p. 73), the judicial enforcement of MLG is seen by these scholars as problematic.

A number of aspects relating to MLG, however, require further study from a legal perspective. The legal bases of MLG still need to be persuasively identified in EU primary law and in the constitutional laws of the MSs. Also, the nature of MLG as a legal principle in the context of the EU demands more compelling corroborating evidence, the normative content of the principle of MLG needs an accurate definition, and the practical 
legal consequences of the principle still need to be clearly determined, particularly the application of MLG by Union and national judiciaries.

These aspects will be examined from a legal perspective. It is only by means of a legal analysis, that is, by interpreting the legal bases of MLG, that it is possible to address these questions and particularly to determine the legal nature and the legal consequences of MLG in the multi-layered legal system of the EU. By the legal system of the EU this paper refers to the "constitutional composite" (Verfassungsverbund, Pernice, 2010 and 2009) or, according to a different terminology, the "fusion" (Wessels, 1997) and the "amalgamation" (Amalgamierung, Nettesheim, 2012, p. 324) resulting from the coordination of the EU and the national legal systems.

MLG will be presented as a constitutional principle in the EU legal system and the consequences of this conclusion will be illustrated. The article is therefore a contribution to a better understanding of MLG in the EU, particularly as a legal concept. It aims to highlight dynamics and possible developments linked to the legal notion of MLG. The article begins with an introduction to the concept of MLG, which distinguishes between descriptive and normative notions of MLG. Then it construes MLG as a legal notion, and more specifically, as a legal principle, by identifying the legal basis of MLG in EU primary law, in the constitutional laws of the MSs, and in EU secondary law. The article goes on to evaluate the role of the Union and of domestic courts in enforcing some aspects of MLG, including subsidiarity, and analyse the soft law mechanisms reflecting MLG. The final paragraph lays out the conclusions.

\section{Sketching Out the Background: The Normative Notion of MLG in the White Papers}

Concerns relating to Type $1 \mathrm{MLG}$ are at the forefront of, in particular, the White Paper on European Governance of the Commission (2001) and the White Paper on MLG of the Committee of the Regions (CoR, 2009). As well as a notion describing the "multi-levelness" of the EU, since the 2001 White Paper MLG has also become a normative notion which goes beyond a mere illustration or explanation of the functioning of the EU and of the multiple political arenas within the EU. In the 2001 White Paper the Commission highlights the importance of communication between sub-national authorities and the EU. To this purpose, the White Paper lays out recommendations with the fundamental objective of enhancing the 
legitimacy of EU decisions, but also promoting "good governance" in the EU (10-11).

Eight years later, the CoR, in the White Paper on MLG, adopted a notion of MLG that is fundamentally "procedural", as it lays out guidelines in relation to how decisions are to be made in the EU. MLG emerges, therefore, as a "method" or "approach": the appropriate method or approach, according to the CoR, for bringing together and coordinating the action of the different levels of government in the EU multi-level system. More specifically, according to the CoR, MLG consists of two key elements: (i) the implementation of EU and national law and policy at regional and local level ("translating European or national objectives into local or regional action") and (ii) the involvement of local and regional authorities in EU law-making and policymaking both at EU and national level ("integrating the objectives of local and regional authorities within the strategies of the European Union ... and encourage their participation in the coordination of European policy") (6-7). The key objectives of the CoR are to enhance the "democratic legitimacy" of Union action and to promote "good governance".

The use of the CoR's notion of MLG comes from an authoritative, although not legally binding source (a white paper of the CoR), but also because it constitutes the basis for recent developments, such as the political document entitled Charter for MLG in Europe (CoR, Resolution on the Charter for MLG in Europe, $106^{\text {th }}$ plenary session, 2 and 3 April 2014, RESOL-V-012). In addition, this notion has the capacity to capture the processes and dynamics of MLG both at the EU level and within the domestic sphere. In the light of this notion, MLG can embrace a number of arrangements such as, in particular: (1) at the domestic level: A) procedures for regional and/or local involvement in EU law-making and policymaking; B) procedures to ensure compliance with EU obligations (e.g., substitute powers of the central government in case of a lack of implementation of EU law by a regional authority); and C) involvement of regional parliaments with legislative powers in the early warning system (Art. 6(1) Protocol on Subsidiarity and Proportionality). Furthermore, at (2) the EU level: A) opening up of the Council to regional representatives at the ministerial level (Art. 16(2) TEU); B) involvement of the CoR, albeit only in a consultative capacity, in the EU decision-making process; C) duty of the Commission to consult widely when making legislative proposals and to take account of the regional and/or local dimension of the action envisaged (Art. 2 Protocol on Subsidiarity and Proportionality); and D) early warning system, which also involves national chambers 
representing sub-national authorities (Articles 6 and 7 Protocol on Subsidiarity and Proportionality).

The shift from a descriptive to a normative notion of MLG is also highlighted in a document of the CoR entitled Scoreboard for monitoring Multilevel Governance (MLG) at the European level 2011 (December 2011): "Against this background, the Committee of the Regions (CoR) wants to strengthen MLG in the different strategic priorities of the EU and in the different stages of the decision-making process at European level. MLG thus acquires a new quality: from analytical tool, it becomes a principle and a programme for action. This demands very concretely the establishment of structured political processes for monitoring and analysing governance in the EU." (p. 2).

The Agenda 2020 of the Commission further emphasises the key normative role of local and regional authorities in delivering EU policy objectives, but also their contribution to the elaboration of the national reform programmes for the implementation of EU strategy (6 and 29). However, the positive or negative impact of (Type 1) MLG is still the subject of debate among scholars. Peters and Pierre (2004, p. 87), for example, identify a "Faustian bargain" in the opaque negotiation of policy taking place among players from different levels within the EU. Similarly, DeBardeleben and Hurrelmann (2007, p. 240) argue that whilst MLG is likely to increase "output legitimacy" (i.e., the problem-solving capacity of the EU), it is also likely to reduce "input legitimacy" (i.e., essentially, democratic legitimacy) because of increased difficulties in calling leaders to account. O Moreover, whilst MLG in the EU may open up new spaces for participation and deliberation, it may also undermine the equal representation of all citizens in the decision-making process. It should be emphasised, however, that these scholars construe MLG essentially as negotiation of policy by sub-national players at the EU level. Yet, the notion of MLG emerging from the CoR's White Paper goes beyond the mere lobbying activity of local and regional offices in Brussels and embraces the "official" channels created at MS as well as at EU level (in particular, the CoR).

Other scholars give a more positive evaluation of MLG. Ingolf Pernice (2002, p. 11) highlights that constitutionalism in the EU (which he calls "multilevel constitutionalism") requires the participation of local and regional authorities in the EU legislative process in order to compensate for the loss of autonomy resulting from the shift of powers to the European level, but also to provide European legislation with the necessary experience and knowledge from the ground. The participation he has in mind includes preliminary consultation with local and regional authorities 
and emphasises the important role of the CoR. Piattoni (2010, p. 178 et seqq.) argues that MLG contributes input and output legitimacy to the EU decision-making process and, in particular, that it contributes positively to democracy in the EU. In the same vein, others suggest that local and regional participation in the EU contributes significantly to constitutionalism and particularly to participatory democracy in the EU (European Parliament, resolution of 14 January 2003 on the role of regional and local authorities in European integration, 2002/2141(INI), Point 4; Mangiameli, 2006, pp. 460-462, 475-476, 480-481; Greenwood, 2011, p. 437 et seqq.; Panara, 2016b, p. 622).

\section{The Legal Notion of MLG}

\subsection{The Constitutional Foundation of MLG at the EU Level}

The first element which is required in order to demonstrate that MLG is a legal principle is the identification of a solid legal basis for MLG in both EU primary law (i.e., the constitutional charter of the EU) and in the constitutional laws of the MSs. Why both? Because MLG envisages a multi-level participation in EU decision-making processes, which requires suitable arrangements and processes at both the EU and national level. Participation in EU decision-making processes is possible only if European institutions open themselves up to such participation and engage with it. At the same time, the involvement of sub-national authorities in the implementation of EU policies is possible only if MSs recognise the prerogatives of these authorities in the fields covered by the EU. This situation largely reflects the idea, put forward by Ingolf Pernice (2010, p. 102 et seqq.), that the EU is a "constitutional composite" (Verfassungsverbund) resulting from national constitutions and EU primary law.

The constitutional foundation of MLG in the EU can be found in Art. 4(2) TEU. According to this, the Union shall respect the national identities of MSs inherent in their fundamental structures, political and constitutional, inclusive of regional and local self-government. Admittedly, it needs to be demonstrated on a case-by-case basis that a certain "constitutional structure" reflects "national identity", and particularly that a certain MLG arrangement reflects that identity and therefore enjoys the protection of Art. 4(2) TEU (Cloots, 2015, p. 125 et seqq.). Yet, the 
constitutional laws of some MSs (for example, Austria, Belgium, Finland, Germany, Italy, Spain, Sweden, and the UK) strongly corroborate the claim that regional and local self-government are an integral part of their "constitutional identity", if not their "national identity", with the result that repeal or limitation of these by force of EU or national law would not be legally feasible without a more fundamental change to the state constitution (Panara, 2013, pp. 373-376).

But how can local and regional self-government be protected by the EU? Given the limited judicial enforceability of Art. 4(2) TEU (infra 3.4.1.), the most straightforward way for EU institutions to enhance the role of sub-national authorities is by promoting their participation in EU decision-making processes. This approach is mirrored by the Treaty provisions concerning the advisory role of the CoR in the law-making process (Art. 13(4) TEU; Warleigh, 1999; Ricci, 2011, pp. 110-111), by Art. 16(2) TEU concerning the opening up of the Council to regional representatives "at ministerial level", but also by Art. 2 of the Protocol on Subsidiarity and Proportionality (duty of the Commission to consult widely before proposing legislation) and Art. 6(1) of the same Protocol on the involvement of regional parliaments with legislative powers in the delivery of reasoned opinions in the framework of the early warning system. This overview corroborates the conclusion that MLG, as defined by the 2009 White Paper, has a constitutional foundation at EU level in EU primary law.

Despite the roots of MLG in EU primary law emphasised above, and despite the fact that there is a constitutional framework for regional and

F local participation, the EU cannot oblige MSs to create participation channels for sub-national authorities, or to use those prompted by the Union. For example, participation in the Council is not only dependent on the EU, but especially on if and to what extent each MS allows sub-state entities to be involved in the Council. In accordance with the "united in diversity" motto, the EU cannot impose uniform patterns on all MSs. The EU can open its gates, but it is ultimately up to the MSs and their regions and local authorities to seize the opportunity. Therefore, the foundation of MLG cannot lie in EU primary law alone.

Furthermore, the guidance offered by EU primary law is rather minimal. Whilst the EU Treaties open up the Union's processes to forms of sub-national participation, there is little prescriptive indication on how these forms of participation should work in practice. For example, the decision on the composition of each (sub-)national delegation to the CoR is largely left up to the MSs. It is up to each MS to strike a balance regarding the representation of different levels of governance (regional and/or local) 
within the CoR. Alone, the opportunities prompted by EU primary law do not offer the whole picture of regional and local participation in the EU. MLG, far from being a monolithic notion, finding application everywhere in the same way, is a largely asymmetrical concept receiving differentiated application in each MS. Accordingly, there is no single pathway to MLG, but potentially twenty-eight different ones.

The White Paper on MLG stresses that "the conditions for good multilevel governance depend on the MSs themselves. The principles and mechanisms of consultation, coordination, cooperation and evaluation recommended at Community level must firstly be applied within the Member States." (ibid. 7). The reflection paper emanating from the Co-Creation Workshop of 16 April 2012 concerning the European Charter on MLG put forward a number of recommendations to the MSs. These include: "stimulate regionalisation and decentralisation", "strengthen further the cooperation between national parliament and regional parliaments, notably on subsidiarity scrutiny", "facilitate the participation of RLA [regional and local authorities] into all stages of the EU policy cycle", and "further develop participation of RLA into the national delegation to the Council formal/informal meetings and comitology" (ibid. 4).

\subsection{The Constitutional Foundation of MLG at the National Level}

At the national level, the foundation of MLG lies in the national constitutions of the MSs. All these constitutions protect regional and/or local autonomy, and in a number of MSs local/regional autonomy is an element of national identity as defined in Art. 4(2) TEU (Cloots, 2015, p. 226). This suggestion is reinforced by the fact that all the EU MSs are also parties to the European Charter of Local Self-Government promoted by the Council of Europe in 1985. This convention stipulates that the principle of local self-government shall be recognised, where practicable, in the national constitution (Art. 2). Therefore, one of the key challenges for the MSs is to ensure a sustainable balance between decentralisation to the sub-national authorities and supranational integration, i.e., centralisation at the EU level. The MSs have developed strategies to reconcile local/ regional autonomy with the growing role of the EU (Panara \& De Becker, 2011; Popelier, 2014). These strategies are reflected in legal (often constitutional) arrangements and perfectly mirror the approach typical of MLG: promoting multi-level participation. 
A strategy to reconcile local/regional autonomy with the EU is the involvement of regional and local authorities in the decision to transfer powers to the EU. The traditional and orthodox EU law perspective is that the MSs are the sole "masters of the Treaties". A reading of Art. 48 TEU on the procedures for amending the Treaties appears to confirm this. However, the transfer of powers from the national level to the EU could undermine the role of local and regional authorities and alter the constitutional balance of powers between central and sub-national governments. This complexity of the EU multi-level system is addressed by certain MSs (in particular Belgium, Finland, Germany, and Austria) through the involvement of sub-national authorities in decisions concerning the European Treaties. For example, Belgian regions and communities have an important say in the transfer of their exclusive powers to the EU. A treaty concerning these powers is ratified by Belgium only if the parliaments of all the regions and communities concerned consent to it. As a result, every sub-state parliament has a right to veto Belgium's ratification of the treaty (De Becker, 2011, p. 256). In Germany, the Länder are involved collectively, as a level of government, in the approval of a treaty. An individual Land does not have right of veto. Every new treaty would need to be approved by a two-third majority in the Bundesrat (the legislative chamber representing the Länder at the federal level), as well as in the Bundestag (the democratically elected chamber representing the German people; Art. 23(1) Basic Law). The German system is similar to the solution adopted in Austria, where amendments to the Treaties require a two-third majority both in the Nationalrat (the chamber representing all the Austrian people) and in the Bundesrat (the chamber representing the Länder at the federal level; Art. 50(1) No. 2 and 50(4) Federal Constitutional Law; Eberhard, 2011, p. 219).

In addition to their ex post involvement in the ratification of a new treaty, MSs may also involve sub-national authorities in the work of an intergovernmental conference (IGC), leading to a new treaty. The German Länder had two representatives in the German delegation to the IGC, which led to the Maastricht Treaty. Their participation contributed to securing the introduction of the principle of subsidiarity, the establishment of the CoR, and the opening up of the Council to regional ministers (Gunlicks, 2003, pp. 366-67). This form of involvement is very important, because the opportunity to negotiate a new treaty could be more effective than the ex post approval (or threat of non-approval) of a treaty already negotiated and agreed on by the national governments.

Another strategy adopted by MSs is the involvement of regional and local authorities in the implementation of EU secondary and tertiary law 
and policy, and in decision-making processes linked to the EU. This is envisaged in the White Paper on MLG of 2009. A number of MSs have a framework in place for the involvement of their sub-national authorities in the choice of the position of the MS in EU decision-making fora (especially the Council) in relation to those policy issues touching upon sub-national responsibilities and interests (see Panara \& De Becker, 2011, p. 297 et seqq.; Eggermont, 2011). This participation can take the form of an agreement between national government and sub-national authorities concerning the position of the MS in the Council (Belgium, Spain); of a consultation of sub-national authorities by the national government (Italy, Portugal, UK); or of more complex decision-making procedures taking place in the Bundesrat, the chamber representing the Länder (Austria and Germany; see, respectively, Eberhard, 2011; Panara, 2011).

This participation enables sub-national authorities to maintain and possibly expand their constitutional role of protecting sub-national interests, while being involved in supranational integration in the EU (Panara, 2010, pp. 82-83). It is apparent that local and regional participation in EU decision-making processes has a constitutional mission. It is constitutionally required by the MSs (at least by those whose constitutional systems include regional and/or local self-government) and, to the extent to which quasi-federal arrangements in the domestic sphere reflect the "national identity" of a MS, also by EU primary law (supra 3.1.). This is an example of how the EU and the national legal orders adjust to each other in the context of the European legal system, in conformity with the doctrine of European public law put forward by Birkinshaw (2014, p. 6 et seqq.), and to the idea, typical of constitutional pluralism, that the EU and the national legal orders have to take into account their respective constitutional requirements as much as possible (cf. in particular Poiares Maduro, 2012).

\subsection{EU Secondary Law}

As well as being rooted in EU primary law as a notion embracing potentially all areas of action by the Union, MLG is also reflected in EU secondary law concerning specifically energy policy, as well as economic, social, and territorial cohesion. Regulation (EU) No. 1233/2010 on EU financial assistance to projects in the field of energy contains a significant reference to MLG. Point 3 of the Preamble establishes that MLG, defined as "cooperation among the various tiers of government", is essential to the 
development of further renewable energy sources and the promotion of energy efficiency. Regulation No. 1233 also creates a dedicated financial facility in support of investment projects related to energy efficiency and renewable energy by local, regional, and national public authorities (Point 4 of the Preamble and Annex II). The notion of MLG as "cooperation" incorporates the idea of coordinated action by various levels of governance for the achievement of European objectives, but also the idea that both the EU and the MSs shall respect the role of sub-national authorities in relation to these objectives. For example, Regulation No. 1233 establishes that the financial support of the Union shall facilitate investments in energy saving, energy efficiency, and renewable energy projects from local, regional, and, "in duly justified cases", also national public authorities (Annex II). Regulation No. 1233 focuses, therefore, on the first dimension of MLG linked to translating European objectives into local and/or regional action. By means of financial intervention, the EU wishes to enhance the role of regional and/or local authorities in relation to energy.

The strongest reference to MLG can be found in Regulation (EU) No. $1303 / 2013$ on EU funding promoting economic, social, and territorial cohesion. This act expressly indicates MLG as a "principle" that, along with subsidiarity and proportionality, must be "respected" by MSs when creating partnerships with sub-national authorities and other economic and social actors for the implementation of the EU economic, social, and territorial cohesion policy. Like in the CoR's White Paper on MLG, in Regulation No. 1303 MLG also emerges as a "procedural" concept, that is, as

F a method of governance which envisages the involvement of sub-national authorities ("In accordance with the multi-level governance approach, the partners ... shall be involved by the MSs in the preparation of Partnership Agreements and progress reports and throughout the preparation and implementation of programmes", emphasis added, cf. Art. 5(2)) and requires "coordinated action" between the different levels of governance ("In order to respect [the] principles [of partnership and MLG] coordinated action is required, in particular between different levels of governance", Point 5.1 (1), Annex I).

Regulation No. 1303/2013 also contains indications concerning the raison d'être of MLG, where it says that respect for the principles of partnership and MLG is required "in order to facilitate achieving social, economic and territorial cohesion and delivery of the Union's priorities of smart, sustainable and inclusive growth" (Point 5.1 (1), Annex I). Accordingly, in the view of the EU legislator, partnership with sub-national authorities finds its justification in the need to enhance the effectiveness of EU social 
and cohesion policy. Similarly, Regulation No. 1303 also stresses that the ultimate purpose of a partnership in the context of EU regional policy is "to ensure the ownership of planned interventions by stakeholders and build on the experience and the know-how of relevant actors" (Point 11 of the Preamble). The phrase "ownership by stakeholders" suggests that the participation of sub-national authorities in EU regional policy could contribute to the acceptance of these policies, i.e., to their legitimacy ("ownership"), as well as to their effectiveness.

The inclusion of MLG as a key principle of EU regional policy sets aside any remaining doubts concerning the nature of MLG as a legal concept. MLG clearly emerges as a principle of procedural nature (i.e., a principle that requires a certain "method" or "approach"), which must be respected by MSs in the field of economic, social, and territorial cohesion. In the context of this policy, MLG is a "principle" (Preamble to Regulation 1303/2013) established by Union law and, as such, its interpretation could theoretically be referred to the Court of Justice via preliminary references arising in domestic courts. Yet, the Court of Justice is likely to adhere to a minimal and procedural notion of MLG. The EU can require that MSs respect a certain "method" or an "approach" when implementing European policies; however, it cannot impose a specific multi-level structure on them. The "method" of MLG commands an appropriate involvement of sub-national authorities and of other relevant players in the preparation and execution of projects in EU economic, social, and cohesion policy. Far from laying out a set of prescriptive rules, in this policy area MLG emerges as a principle, and more specifically, as a "procedural principle", indicating in general bow decisions shall be made and implemented. The added value of this method is an increased legitimacy and effectiveness of EU regional policy.

\subsection{The Role of the Courts}

The Court of Justice of the EU. The justiciability of a principle is not essential in order to conclude that that principle is a legal and not a philosophical or political notion. For example, the justiciability of the principle of subsidiarity is very limited and controversial, and yet that principle remains a constitutional cornerstone of the EU (Van Nuffel, 2011, p. 78; Panara, 2016a, p. 305 et seqq.). Similarly, judicial enforcement of various aspects of MLG does not need to be the primary route for ensuring compliance at the EU and national level (Winter \& May, 2001, p. 675 et seqq.). Still, the 
traditional, widely accepted notion of constitutionalism as a "legal limitation on government" (McIlwain, 1947, p. 21; see also along the same lines Morbidelli 2010, p. 66; de Vergottini, 2007, p. 177 et seqq.) highlights that a legal limitation on power does not only require an adequate system of political rights and freedoms and of checks and balances in the political process. It also requires an important role of the judiciary in enforcing the legal limits to the exercise of political powers, particularly by means of constitutional adjudication (Matteucci, 2010 [1964], p. 91; Nolte, 2005, pp. 16-18). This and the following section will show how both Union and domestic courts have a role to play in enforcing and shaping MLG. There are fundamentally three ways in which the judiciary of the Union can play a role: (1) in relation to the Treaty articles embodying the idea of MLG, (2) in relation to the concept of "national identity" of Art. 4(2) TEU, and (3) in relation to acts of secondary law which contain reference to and embody the concept of MLG.

(1) In relation to those norms of EU primary law which embody or reflect MLG, Union courts can play the ordinary role they would play in relation to any other primary law rule. For example, lack of consultation of the CoR when this is compulsory could lead to the annulment of the relevant act by the CJ. The CoR itself could request the annulment via direct action pursuant to Art. 263(3) TFEU. Admittedly, though, it is difficult to imagine a possible role for the $\mathrm{CJ}$ in relation to regional participation in the Council (Art. 16(2) TEU) and to the involvement of regional parliaments with legislative powers in the delivery of reasoned opinions in the O framework of the early warning system (Art. 6(2) Subsidiarity Protocol).

The legal position is potentially different in relation to the duty of the Commission to consult widely before drafting a legislative proposal (Art. 2 Subsidiarity Protocol). This is an important channel for political cooperation and dialogue, which may help the Commission and law-making institutions to focus on the potential impact of a regulation. It is unlikely that the CJ would uphold the claim that a certain act is unlawful for lack of, or inadequate, preliminary consultation. However, the Union judiciary has already expressly recognised that consultation contributes legitimacy to the EU law-making process. In the case of UEAPME, the Court of First Instance (hereafter CFI) held that whenever the European Parliament does not participate in the enactment of a legislative act, the principle of democracy requires an alternative form of participation by the people. If such participation takes the form of social dialogue, the Commission and the Council have an obligation to verify that the social partners involved are sufficiently representative. Only in this way can the 
democratic legitimacy of the EU law-making process be preserved (Case T-135/96, UEAPME v. Council [1998] ECR II-2335 para. 88-89; Smismans, 2004, p. 340 et seqq.; Popelier, 2011, p. 567; White Paper on European Governance, 2001, p. 11).

(2) Article 4(2) TEU appears likely to lend itself to judicial enforcement in relation to MLG only in extreme circumstances. Probably, like for subsidiarity (Panara, 2016a, p. 321; contra Schütze, 2009b and Vandenbruwaene, 2012 and 2013, who argue in favour of stricter judicial scrutiny of subsidiarity), only a clear instance of abuse, such as an EU regulation on economic, social, and cohesion policy completely ignoring the role of sub-national authorities, would find Union courts willing to annul it for a breach of Art. 4(2) TEU. An analysis of the jurisprudence of Union courts on Art. 4(2) TEU in relation to regional and local autonomy offers important insights regarding MLG.

As previously stated, the implementation of EU law and policy by sub-national authorities is a constitutive element of MLG as defined in the 2009 White Paper of the CoR (supra 2). This aspect came to the fore in a few cases concerning or surrounding Art. 4(2) TEU: Commission v. Spain (2013) and Digibet (2014).

An interesting statement going in this direction can be found in the Opinion that Advocate General Kokott delivered in the case of Commission v. Spain, concerning a failure by the Spanish autonomous communities to implement Directive 2000/60/EC on the water policy of the EU. In response to the argument advanced by Spain, that a national regulation transposing the directive had already ensured full compliance with EU rules, Kokott noted that this method of transposition (i.e. the subsidiary application of national rules) is probably in breach of Spanish constitutional law, because it does not acknowledge the legislative responsibility associated with the legislative power of the regional authorities. Through this argumentum ad adiuvandum AG Kokott implicitly recognised that the responsibility of the autonomous communities for the implementation of EU law in the areas falling within their legislative remit is an essential part of the constitutional identity of the Spanish state (Opinion of AG Kokott 30 May 2013, Case C-151/12, Commission v. Spain, para. 34-35).

More recently, the CJ had an opportunity to clarify that "the division of competences between the [German] Länder cannot be called into question, because it benefits from the protection conferred by Article 4(2) TEU" (Case C-156/13, 12 June 2014, Digibet Ltd and Gert Albers v. Westdeutsche Lotterie GmbH \& Co. OHG, para. 34). Also, the Court reiterated the principle, already sketched out in earlier case law (Joined Cases 
51-54/71, 15 December 1971, International Fruit Company NV and others v. Produktschap voor Groenten en Fruit), that the EU cannot alter the allocation of responsibilities within MSs (Case C-156/13, Digibet, para. 33). The Opinion of AG Mengozzi in the case of RegioPost, reflected in the judgment of the Court in the same case, says in express terms that "it is clear from Art. 4(2) TEU that EU law cannot prevent a regional or local entity from actually exercising the powers vested in it within the MS concerned." (para. 84 of the Opinion). Accordingly, the Land of Rhineland-Palatinate is entitled to pass legislation requiring the tenderers of a public procurement contract and their subcontractors to pay a minimum hourly wage to staff involved in the execution of the contract (Opinion of AG Mengozzi 9 September 2015, Case C-115/14, RegioPost GmbH \& Co. KG v. Stadt Landau; Case C-115/14, 17 November 2015, RegioPost GmbH \& Co. KG v. Stadt Landau).

At the same time, the Court has always consistently maintained that the internal allocation of competences within a MS (between central, regional, or local authorities) cannot in any way release that MS from fulfilling its obligations under EU law (CJEU 8 September 2010, Case C-46/08, Carmen Media Group Ltd v. Land Schleswig-Holstein, Innenminister des Landes Schleswig-Holstein, para. 69; 13 September 2001, Case C-417/99, Commission v. Spain, para. 37; 28 February 1991, Case C-131/88, Commission v. Germany, para. 71; 14 January 1988, Joined Cases 227-230/85, Commission v. Belgium, para. 9).

Admittedly, however, the expansive force of Art. 4(2) TEU in relation to the role of sub-national authorities seems to be limited (contra, it would appear, Cloots, 2015, p. 226 et seqq.). The General Court dismissed the argument that the lack of recognition of locus standi of Northern Ireland goes against the obligation of the EU (stemming from Art. 4(2) TEU) to respect the national identity of the UK, including its regional self-government. According to the Court "such an obligation does not in any way impinge on the Treaty provisions on judicial remedies" (Case T-453/10, 6 March 2012, Northern Ireland Department of Agriculture and Rural Development v. Commission, para. 36-38, the quote is from para. 38). This statement reflects the consolidated position of Union courts on the lack of privileged applicant status of the sub-national authorities in direct challenges under Art. 263 TFEU (see, ex multis, ECJ 11 July 1984, Case 222/83, Municipality of Differdange v. Commission, para. 8; 21 March 1997, Case C-95/97, Région Wallonne v. Commission, para. 6-7; 1 October 1997, Case C-180/97, Regione Toscana v. Commission, para. 7-8; 30 April 1998, Case T-214/95, Vlaams Gewest v. Commission, para. 28; see also Gamper, 
2013, pp. 118-120; Thies, 2011, p. 25; Dani, 2004). This judicial position leaves a gap in the judicial protection of the rights of sub-national authorities in the EU. This gap is not overcome by the judicial remedies available pursuant to Articles 267 and 277 TFEU (Panara \& De Becker, 2011, p. 324). More effective ways of filling this gap have been developed at the domestic level by the creation of tools enabling sub-national authorities, individually (like in Belgium) or collectively (like in Italy and Germany), to oblige the national government to file an action for direct annulment before Union courts pursuant to Art. 263 TFEU (Panara \& De Becker, 2011, p. 326).

(3) The CJEU could be asked to correctly interpret the concept of MLG through a preliminary reference, when this concept is used in EU secondary law. To date, only Regulation (EU) No. 1233/2010 on renewable energy sources and Regulation (EU) No. 1303/2013 on EU economic, social, and cohesion policy refer expressly to MLG.

In summary, the legal nature of MLG is confirmed by the current and potential role of the Court of Justice of the EU in relation to the enforcement of certain aspects of the notion of MLG: the participation in EU decision-making processes, the implementation of EU law and policy, and, finally, the interpretation of the notion of MLG put forward by EU secondary law.

Domestic courts. Domestic courts, especially constitutional courts, can play a role in the enforcement of some aspects of MLG at the national level. More specifically, they can play a role by: (1) sanctioning a failure to comply with participatory arrangements established by national law, (2) preserving the right and duty of local and regional authorities to implement EU law and policy, and, finally, (3) contributing to the definition of important concepts such as "national identity", "fundamental structures, political and constitutional", and "regional and local self-government" (Art. 4(2) TEU).

(1) If participatory arrangements established by domestic law are not observed, the sub-national authorities in some MSs are theoretically entitled to instigate judicial proceedings in domestic courts to enforce their participation rights. This might be the case in Italy and Spain, where the rights of sub-state authorities could be enforced in constitutional or administrative courts (Panara \& De Becker, 2011, pp. 315-317) and, with greater difficulty, in Austria (Panara \& De Becker, 2011, pp. 316-317). This might also be the case in Germany. The constitutional participatory rights of the German Länder through the Bundesrat are in principle en- 
forceable in the Federal Constitutional Court (see Art. 93(1), No. 1 and No. 3, Basic Law). However, in 1995 the Court found that the Federal Government had not respected the rights of the Bundesrat in relation to Directive 89/522/EEC on TV. The Court held that this behaviour was in breach of the principle of federal loyalty (Ruling of the Federal Constitutional Court of 22 March, 1995). Nevertheless, this declaration did not result, nor could it, in the invalidity of the directive. Admittedly, the impossibility of declaring the invalidity of the final act could undermine the effectiveness of the judicial intervention. This example suggests that, in case of non-compliance with participatory arrangements, the sanction for a national government might be political (and might concern the legitima$c y$ of an action), rather than legal (and lead to the invalidity of an action).

The primary problem with the enforcement of participation rights of regional authorities is therefore the following: should a national court find that a domestic law provision has not been complied with, that court would still not be entitled to declare the invalidity (or the inapplicability) of the EU measure. According to the "orthodox" EU perspective, the invalidity of EU legislation can be declared only by Union courts. Another problem is that it could take some time before a domestic court passed a ruling on the judicial enforcement of regional participation rights. This would not necessarily be compatible with the speed of EU decision-making processes. This situation surely limits the effectiveness of national provisions regulating the participation rights of sub-state entities. This explains why regional authorities generally prefer to settle their disputes with the national government politically, in conformity with the principle of loyal cooperation, rather than judicially (Panara \& De Becker, 2011, p. 318).

(2) Sub-national authorities have a primary responsibility for the implementation of EU law and policy in those areas falling within their remit. This principle is explicitly (UK, Section 53 and Paragraph 7(2) of Schedule 5 of the Scotland Act 1998, Paragraph 3(c) Schedule 2 of the Northern Ireland Act 1998, Section 80 of the Government of Wales Act 2006; Italy, Art. 117(5) of the Constitution) or implicitly (Germany, Belgium, Spain) entrenched in the constitutional systems of the MSs (Panara \& De Becker, 2011, pp. 333-335). Constitutional courts can definitely play a role in ensuring that the implementation of EU law and policy follows the internal allocation of responsibilities between national and sub-national authorities. Even in the UK, where certain arrangements concerning devolution and MLG are "binding in honour only", in the event of a disagreement between the UK government and devolved administrations 
over whether a particular issue falls within a devolved competence or is retained by Westminster, the dispute might be referred to the Supreme Court (Paragraph B4.9 of the Concordat on the Co-ordination of EU Policy of September 2012).

The rule that the implementation of EU law and policy shall follow the internal distribution of responsibilities admits only limited and justifiable exceptions, although the boundaries of these exceptions are uncertain and vary from state to state. The Italian Constitutional Court (Ruling No. 126 of 24 April 1996) stated that an alteration of the normal distribution of competences between the state and regions may exceptionally be accepted if the proper implementation of an EU regulation required the adoption of uniform rules across the entire national territory. In the Ruling of 14 October, 2008 concerning EC Regulation No. 1782/2003, the German Federal Constitutional Court (Bundesverfassungsgericht) held that the proper implementation of the Regulation required a federal statute in order to safeguard the legal and economic unity of the country (para. 88-89).

The Austrian Constitutional Court created the interesting notion of doppelte Bindung (double bond). The domestic legislator is indeed "bound twice". On the one hand, it has to comply with EU obligations, and on the other hand with the national constitution, including the distribution of responsibilities between Federation (Bund) and Länder. The Länder have the constitutional right and, at the same time, the duty, to implement EU law and policy within their sphere of responsibility and territory. If in a matter within the remit of the Länder an EU act required uniform implementation within the national territory, it would be necessary to amend the constitution (Austrian Constitutional Court 14.863/1997 and 17.022/2003). However, if, pursuant to Art. 258 TFEU, the Court of Justice found that an Austrian Land failed to comply with an obligation under EU law, the responsibility to adopt the necessary measures would pass temporarily to the Federation ("substitute power", Art. 23d, paragraph 5, final sentence, B-VG; Eberhard, 2011, pp. 229-230).

Substitute state powers as a tool for the implementation of EU law and policy are also in place in other MSs such as Italy, Spain, and Belgium (Panara \& De Becker, 2011, pp. 336-340). The constitutional distribution of powers between central government and regional level could be seriously undermined if substitute powers were exercisable a priori, i.e., before the non-fulfilment of an EU obligation and in order to prevent it from occurring. The Spanish Constitutional Court envisaged that a substitute power can be exercised only after the non-fulfilment of an EU ob- 
ligation by a region has taken place (Spanish Constitutional Court Ruling No. 80 of 8 March 1993). Such a clear stance, however, has not been taken by constitutional courts in other MSs, such as Italy, where a priori substitution is the rule, even though regional authorities can replace the implementing measures issued by the central government with their own (Villamena, 2011, p. 175).

(3) The concept of "national identity" (and those of "fundamental structures, political and constitutional" and "regional and local self-government" of Art. 4(2) TEU) is a notion of EU law and as such its content shall be further specified by the CJEU. However, the specific content of "national identity" is also likely to result from the way each MS understands its own identity. Accordingly, the CJEU might also have to rely on national law and particularly on the case law of the constitutional courts (von Bogdandy \& Schill 2010, p. 8; Streinz, 2012, p. 28; see also the Ruling of the German Federal Constitutional Court on the ratification of Treaty of Lisbon of 30 June 2009).

In summary, again, the legal nature of MLG is confirmed by the role of domestic courts, in particular in relation to: (1) ensuring that national authorities comply with participatory arrangements established by national law and linked to MLG, even though in practice the effectiveness of these remedies is limited; (2) protecting the right (and duty) of local and regional authorities to implement EU law and policy within their remit, although this right of regional authorities has occasionally been restricted by the courts (for example, in Italy and in Germany) and through the creation of state substitute powers; and, finally, (3) in relation to the potential contribution of domestic courts to the specification of the content of Art. 4(2) TEU from a national perspective.

\subsection{MLG and Subsidiarity}

Another issue closely related to MLG is subsidiarity. Pursuant to Art. 5(3) TEU, "the Union shall act only if and insofar as the objectives of the proposed action cannot be sufficiently achieved by the MSs, either at central level or at regional and local level". According to some scholars, subsidiarity is a political or philosophical concept and, as such, its judicial enforcement is impossible or extremely difficult (Working Group I 2002, p. 2; Barber, 2005a; Toth, 1994, p. 282). The Court of Justice of the EU seems to perceive this principle as a "threat to integration" (Estella, 2002, p. 178), as "totally alien" to the EU (Toth, 1992, p. 1079), and in conflict 
with the "broad ethos" of the Court (Barber, 2005b, p. 199). The constitutional relevance of this problem is high, because it is linked to the general problem of constitutionalism as a legal limitation to political power (McIlwain, 1958 [1947], p. 21), which in turn presupposes a judicial review of the actions of public authorities (Matteucci, 2010 [1964], p. 91; Barberis, 2012, pp. 20-21).

Van Nuffel (2011, pp. 65-66) criticises the opinion depicting the Court of Justice as "consistently unwilling to review Community legislation for alleged violations of subsidiarity" (Cooper, 2006, p. 284). Even though it is a hard fact that there has been no single case before the Court of Justice that has resulted in the annulment of an act for breach of subsidiarity, analyses of the cases concerning subsidiarity highlight that the Court does not uphold EU action without appropriate scrutiny (Van Nuffel, 2011, pp. 65-66; Craig, 2012, p. 80; Panara, 2016a, p. 319; contra Vandenbruwaene, 2013, p. 159). According to these analyses, the circumstance that until now no act of the Union has been annulled for a breach of that principle is essentially due to the limited number of cases in which subsidiarity pleas have been brought before the Court (Craig, 2012, p. 80) and to the fact that in all cases there were persuasive justifications for the action of the Union (Van Nuffel, 2011, pp. 65-66; see, inter alia, Case C-84/94, UK v. Council [1996] ECR I-5755; Case C-377/98, Netherlands v. European Parliament and Council [2001] ECR I-7079; Case C-491/01, The Queen v. Secretary of State for Health (ex parte British American Tobacco Ltd.) [2002] ECR I-11453; Joined Cases C-154/04 and C-155/04, ANH v. Secretary of State for Health [2002] ECR I-6451; Case C-103/01, Commission v. Germany [2003] ECR I-5369; Case C-58/08, The Queen v. Secretary of State for Business (ex parte Vodafone) [2010] ECR I-4999; Case C-508/13, Estonia v. European Parliament and Council, EU:C:2015:403; Case T-257/13, Poland v. Commission, EU:T:2015:111; Case C-358/14, Poland v. European Parliament and Council, EU:C:2016:323).

In no circumstances did the Court come to a conclusion in relation to subsidiarity which was different from that advised by the Advocate General (AG). Whilst, admittedly, the opinions of some Advocates General entail a surface scrutiny of subsidiarity (see, for example, AG Geelhoed's Opinion in Joined Cases C-154/04 and C-155/04 ANH v. Secretary of State for Health), others have been quite thorough when tackling the same issue (AG Poiares Maduro, Opinion in Case C-58/08, The Queen v. Secretary of State for Business (ex parte Vodafone); AG Jääskinen, Opinion in Case C-507/13, UK v. European Parliament and Council [para. 101 et seqq.]; AG Kokott, Opinion in Case C-358/14, Poland v. European Parliament 
and Council; AG Léger Opinion in Case C-84/94, UKv. Council [Working Time Directive]).

It is difficult to picture how the Court of Justice could give more substance to the rights of regional and local authorities through subsidiarity. None of the cases on subsidiarity have ever concerned regions or local authorities within the MSs directly, and the protection of regional and local authorities in Art. 5(3) TEU has so far remained on paper (Van Nuffel, 2011, p. 61). MLG envisages participation by sub-national authorities in EU decision-making processes (cf. 2 supra and CoR White Paper MLG, 2009). Therefore, whilst subsidiarity is judicially enforceable in extreme circumstances of clear abuses, MLG pushes towards multi-level cooperation or procedural mechanisms alternative to judicial enforcement in order to ensure compliance with subsidiarity (Panara, 2015, pp. 121-122).

The most important procedural innovation introduced by the Lisbon Subsidiarity Protocol is certainly the "early warning system" (Articles 6 and 7), a mechanism aiming to create a dialogue between national parliaments and Union institutions during the legislative process. Whilst it is not easy to reach the minimum number of votes for triggering a "yellow" or an "orange card" (so far only two yellow cards have been issued), the early warning system is potentially important for regional participation in EU decision-making processes in that national parliaments shall consult with regional parliaments with legislative powers (Art. 6(1)). In theory, the early warning system could also modify the traditional self-restraint of the Court of Justice in relation to subsidiarity. The evidence contained in the

P reasoned opinions of national parliaments and of the Commission could be taken into account by the Court of Justice when addressing a subsidiarity complaint. Additionally, the procedural requirements of the early warning system seem to be judicially enforceable and failure to comply with these could lead to the invalidation of an act by the Court. In this way, however, the Court would be enforcing certain procedural requirements rather than subsidiarity per se (Panara, 2016a, pp. 327-328).

A similar tendency towards "proceduralisation" can be seen in the role of the CoR in relation to subsidiarity. When performing its consultative role, the CoR will normally express its point of view on the conformity of a legislative proposal with subsidiarity (Art. 55(2) CoR's Rules of Procedure; Ricci, 2011, pp. 123-126). The Lisbon Subsidiarity Protocol gave the CoR the right to challenge a legislative act on grounds of infringement of subsidiarity (Art. 8(2)). Despite that, the CoR does not appear particularly confident that subsidiarity can be enforced through judicial review. So far no challenge has been lodged by the CoR against an act for infringement 
of subsidiarity. Admittedly, it cannot be ruled out that the right to challenge, albeit not yet exercised, may have strengthened the opinions of the CoR vis-ã-vis law-making institutions. For this reason, the CoR may be playing a stronger role in the legislative process, in which case compliance with subsidiarity would stem from multi-level dialogue and cooperation between political actors rather than from judicial scrutiny.

The procedural requirement for the Commission to consult the CoR (albeit not only in relation to subsidiarity) regarding proposals in certain policy areas is judicially enforceable. Pursuant to Art. 263(3) TFEU the CoR has the status of a privileged applicant when challenging an act to protect its constitutional prerogatives. Like in the early warning system, however, there would be a shift of focus of the judicial review from subsidiarity per se to the enforcement of certain procedural requirements linked to subsidiarity. This is why Nettesheim (2014) labels subsidiarity as politisches Recht (political law), an oxymoronic notion indicating those legal provisions which are only or principally enforceable through forms of political coordination.

\subsection{Soft Law Mechanisms}

Alongside the hard law mechanisms illustrated previously (supra 3.1., 3.2. and 3.3.), there are soft law instruments at EU level which promote multi-level participation of sub-national authorities in the EU. A tool prompted by the Commission in the wake of the 2001 White Paper is the structured dialogue created by the Commission's communication (Communication from the Commission COM (2003) 811 final of 19 December, 2003) and by a decision of the CoR (CoR's Bureau Decision CoR 380/2003, part II, of 19 March, 2004). The structured dialogue consists of meetings between representatives of the Commission and selected European and national associations of sub-national authorities. These associations are identified by the Commission, upon advice from the CoR. The meetings of the structured dialogue may concern the annual work programme of the Commission ("general dialogue") or a particular policy area ("thematic dialogue"; in the literature cf. Vara Arribas, 2005, p. 19 et seqq.; Domenichelli, 2007, p. 71 et seqq.; Ricci, 2011, p. 122).

In 2006 the European Commission launched a political dialogue with national parliaments (Communication to the European Council, A Citizens" Agenda, Brussels, 10 May 2006, COM (2006) 211 final, p. 9). Due to the flexible nature of political dialogue compared to, for example, the 
early warning system (political dialogue is not limited to subsidiarity in relation to legislative acts, nor is it bound by rigid deadlines), national parliaments or chambers thereof (including those houses representing regional authorities such as, in particular, the German Bundesrat), use this tool more frequently than the early warning system. In 2014, 506 opinions were issued by national parliaments, but only 21 of those were reasoned opinions issued in the context of the early warning system (Commission 2014: Annex 1). In 2015, 350 parliament opinions were issued, but only 6 of those in the context of the early warning system (Commission 2015: Annex 1).

\section{Conclusion}

The preceding legal analysis of MLG suggests that MLG, as defined in the White Paper of 2009, is a legal as well as a normative notion. The nature, scope, and sphere of application of MLG go significantly beyond the traditional descriptive notion of MLG of the early days (Marks, 1992; Hooghe \& Marks, 2001). MLG has a constitutional foundation both at the EU and at national level. The fundamental idea of MLG is rooted in legal arrangements both at the EU and at national level, as well as in hard and soft law mechanisms. MLG envisages participatory solutions to constitutional problems linked to the position of local and regional authorities in EU integration.

MLG is normatively linked to the principles of local and regional autonomy and of subsidiarity. It operationalises these in the multi-level context of the EU by envisaging participation by local and regional authorities in EU decision-making processes and in the implementation of EU law and policy. MLG has the characteristics of a legal concept and, more specifically, of a legal principle. It is sufficiently "general" and "fundamental" to be a principle, but at the same time it is sufficiently prescriptive to indicate a way forward in terms of the future direction and development of the EU. It can be classified as a "procedural" principle, which focuses on bow decision-making processes shall be structured within the EU and on who has to participate in these processes. It can also be described as an "accessory" principle in that it is functional to the normative values embodied in local and regional autonomy and in subsidiarity (Panara, 2016a, pp. 305-306).

This study has identified four functions of MLG as a legal notion in the EU. 
1. Epistemological function concerning the nature of the EU. Quite rightly, Marks and Hooghe argue that federalism is the intellectual foundation of Type 1 MLG (Marks \& Hooghe, 2004, p. 17). The EU, like federal or regional states, is a multi-level system (Benz, 2009). These systems feature a plurality of mutually interacting layers of governance and, despite significant differences, belong to the same fundamental family, the "federations" (Schütze, 2012, pp. 77-79). The legal notion of MLG adds to this background a constitutional traction towards multi-level cooperation in relation to the shaping and implementation of EU laws and policies. It envisages a strong cooperative philosophy for the $\mathrm{EU}$, which is remindful of cooperative federalism, based on participation by sub-national authorities in the decision-making processes of a central authority, as opposed to the rigid separation of spheres of responsibility typical of dual federalism (on "dual" and "cooperative federalism" cf. Reposo, 2005; Bognetti, 1994; de Vergottini, 1990).

2. De iure condendo function. As a bi-dimensional (both national and EU) constitutional principle, MLG pushes towards a certain development of the EU as a multi-level system. It is a principle remindful of the "programmatic rules" of some national constitutions (Crisafulli, 1952). These rules lay out objectives for the legislator in various areas, from economy to education or healthcare. MLG is similar to these "rules" in that it lays out a "plan of action" concerning how the EU and its MSs have to structure the relationship between layers of governance within the EU. As previously stated, the mutual convergence of the EU and its MSs towards MLG reflects the idea, typical of constitutional pluralism, that the EU and national legal orders shall take into account their respective constitutional requirements as much as possible (Poiares Maduro, 2012). A Treaty amendment that would go in the fundamental direction of MLG would be, for example, an extension of the eight-week period for the release of a reasoned opinion. This would enhance regional participation in the early warning system and promote compliance with the principle of subsidiarity.

3. Behaviour-shaping function. Because it is normatively linked to local/ regional autonomy and subsidiarity, MLG as a procedural principle on bow to make decisions in the EU shall guide the behaviour of actors in the EU political arena. The Commission, for example, shall consult "widely" before proposing legislation (Art. 2 Subsidiarity Protocol) and the consultation shall include local and regional actors. 
Where appropriate, the proposed legislation shall create participation mechanisms for these actors (see, for example, the "partnerships" with local and regional authorities envisaged by EU Regulation No. 1303/2013).

Compliance with subsidiarity in particular can be enhanced through mechanisms of multi-level cooperation and dialogue, such as structured and especially political dialogue, and lead to legislation more respectful of the autonomy of sub-national authorities and MSs. On the other end of the spectrum, as well as the EU and the MSs, local and regional actors shall also actively engage with the EU and utilise the participation opportunities prompted by the EU.

4. Interpretation-shaping function. MLG as a legal principle shall also guide the interpretation and application of the law by the courts and particularly the Court of Justice of the EU in relation to: subsidiarity, enforcement of the participation rights of local and regional authorities, and the locus standi of local and regional authorities in direct challenges to EU acts in Union courts. In relation to subsidiarity, the application of MLG should lead not only or necessarily to stricter judicial scrutiny of Art. 5(3) TEU. Rather, it should ensure compliance with subsidiarity ex ante, during the law-making process, through multi-level dialogue and cooperation (for example, through consultation of the CoR or the early warning system) and the enforcement of these procedural requirements by the Court of Justice.

As to the participation rights of sub-state authorities, the "orthodox" EU law position - in principle - of indifference to decision-making processes internal to the MSs would lead the Court of Justice to ignore any infringements of these rights by the MSs. This position reflects a residual "regional blindness" of the EU, i.e., its traditional tendency (until the 1990s) to completely ignore sub-national authorities (on the concept of "regional blindness", Landesblindheit, see Ipsen, 1966). This disadvantage for the regions could be addressed by the Court of Justice, if it chose to consider unlawful EU acts for a breach of national rules concerning regional participation. A judicial enforcement of the participation rights of the regions could find its legal basis, apart from in the principle of MLG, in the protection of "national identity" pursuant to Art. 4(2) TEU, or in the Vienna Convention on the Law of the Treaties (Art. 46). However, it would need to be demonstrated in each case that an infringement of regional participation amounts to a violation of "national identity" or to a manifest violation of a rule of internal law of fundamental importance respectively. 
Finally, MLG could mitigate the consolidated position of the Court of Justice on the locus standi of local and regional authorities and establish an interpretation of Art. 263(3) TFEU which would make it easier for local and regional authorities to challenge the validity of acts which have a detrimental impact on their responsibilities and interests (AG Jacobs, Opinion in Case C-50/00 P, Unión de Pequeòos Agricultores v. Council, para. 102, although not specifically in relation to sub-national authorities).

In summary, the legal analysis identifies a compelling legal basis for MLG. This in turn becomes a more stable concept with a constitutional foundation, and less exposed to political dispute. The legal analysis also identifies the potential of MLG for the interpretation of EU law and for shaping future developments within the EU legal system.

\section{References}

Abels, G. (2011). Wandel oder Kontinuität? Zur Europaarbeit der deutschen Landesparlamente nach dem Lissabon-Vertrag und dem Lissabon-Urteil des Bundesverfassungsgerichts. [Change or continuity? On the European activity of the parliaments of the German Länder after the Lisbon Treaty and the Lisbon judgment of the Federal Constitutional Court] In G. Abels \& A. Eppler (Eds.), Auf dem Weg zum Mebrebenenparlamentarismus? Funktionen von Parlamenten im politischen System der EU (pp. 17-40). Baden-Baden, Germany: Nomos.

Bache, I. (2004). Multi-level governance and European Union regional policy. In I. Bache \& M. Flinders (Eds.), Multi-level governance (pp. 165-178). Oxford, United Kingdom: Oxford University Press.

Barber, N. W. (2005a). The limited modesty of subsidiarity. European Law Journal, 11(3), 308-325.

Barber, N. W. (2005b). Subsidiarity in the draft constitution. European Public Law, 11(2), 197-205.

Barberis, M. (2012). Stato costituzionale [The constitutional state]. Modena, Italy: Mucchi.

Benz, A. (2009). Politik in Mebrebenensystemen [Policy in multi-level systems]. Wiesbaden, Germany: VS Verlag für Sozialwissenschaften.

Bernard, N. (2002). Multilevel governance in the European Union. New York, NY: Kluwer Law International.

Birkinshaw, P. (2014). European public law: The achievement and the challenge (2nd ed.). New York, NY: Kluwer Law International. 
Bognetti, G. (1991). Federalismo. [Federalism] In Digesto delle discipline pubblicistiche. Vol. VI (pp. 273-302). Turin, Italy: UTET.

Cloots, E. (2015). National identity in EU law. Oxford, United Kingdom: Oxford University Press.

Commission of the European Union (2015). Annual report 2014 on relations between the European Commission and national parliaments( COM (2015) 316 final, 2 July). Brussels, Belgium.

Commission of the European Union (2016). Annual report 2015 on relations between the European Commission and national parliaments (COM (2016) 471 final, 15 July). Brussels, Belgium.

Committee of the Regions (2011). Scoreboard for monitoring multilevel governance (MLG) at the European level 2011 (Research coordinated by Gracia Vara Arribas \& Martin Unfried). Brussels, Belgium: Author.

Committee of the Regions (2012). Co-creation workshop: Elements of a EU charter on multilevel governance [Reflection paper]. Brussels, Belgium: Author.

Cooper, I. (2006). The watchdogs of subsidiarity: National parliaments and the logic of arguing in the EU. Journal of Common Market Studies, 44(2), 281-304.

Craig, P. (2012). Subsidiarity: A political and legal analysis. Journal of Common Market Studies, 50(S1), 72-87.

Crisafulli, V. (1952). Le norme «programmatiche» della Costituzione. [The "programmatic" norms of the Constitution] In Studi di diritto costituzionale in memoria di Luigi Rossi (pp. 51-83). Milan, Italy: Giuffrê.

Cygan, A. (2013). Regional governance, subsidiarity and accountability within the EU's multi-level polity. European Public Law, 19(1), 161-188.

Cygan, A. (2014). The regions within multi-level governance: Enhanced opportunities for improved accountability? Maastricht Journal of European and Comparative Law, 21(2), 265-280.

Dani, M. (2004). Regions standing before the EU courts: Towards a constitutional theory on "direct and individual" participation of the regions in the EU decision-making processes. In R. Toniatti, F. Palermo \& M. Dani (Eds.), An ever more complex union (pp. 181-197). Baden-Baden, Germany: Nomos.

DeBardeleben, J., \& Hurrelmann, A. (2007). Conclusion. In J. DeBardeleben \& A. Hurrelmann (Eds.), Democratic dilemmas of multilevel governance (pp. 240243). New York, NY: Palgrave-Macmillan.

De Becker, A. (2011). The state and sub-state entities are equal, but is the state sometimes still more equal than the others? In C. Panara \& A. De Becker (Eds.), The role of the regions in EU governance (pp. 251-274). Berlin, Germany: Springer.

De Vergottini, G. (1990). Stato federale [The federal state]. In Enciclopedia del Diritto. Vol. XLIII (pp. 831-860). Milan, Italy: Giuffrê.

De Vergottini, G. (2007). Diritto constituzionale comparato, 7th ed. [Comparative constitutional law]. Vol. I. Padua, Italy: CEDAM (7th ed.).

Domenichelli, L. (2007). Le regioni nella Costituzione europea [The regions in the European Constitution]. Milan, Italy: Giuffrê. 
Dubos, O. (2012). Le paradigme du «multilevel governance» est-il soluble dans le droit? [Is the paradigm of "multilevel governance" solvable in law?] Revue $d u$ marche commun et de l'Union européenne, 556, 144-149.

Eberhard, H. (2011). The role of the "länder" in a "centralised federal state". In C. Panara \& A. De Becker (Eds.), The role of the regions in EU governance (pp. 215-232). Berlin, Germany: Springer.

Eggermont, F. (2011). In the name of democracy: The external representation of the regions in the Council. In C. Panara \& A. De Becker (Eds.), The role of the regions in EU governance (pp. 3-24). Berlin, Germany: Springer.

Eppler, A. (2011). Vertikal und horizontal, bi- und multilateral: Interparlamentarische Beziehungen in EU-Angelegenheiten [Vertical and horizontal, bilateral and multilateral: Interparliamentary relations in EU affairs]. In G. Abels \& A. Eppler (Eds.), Auf dem Weg zum Mebrebenenparlamentarismus? Funktionen von Parlamenten im politischen System der EU (pp. 297-315). Baden-Baden, Germany: Nomos.

Estella, A. (2002). The EU principle of subsidiarity and its critique. Oxford, United Kingdom: Oxford University Press.

Gamper, A. (2013). Regions and constitutional courts in a multilayered Europe. In P. Popelier, A. Mazmanyan \& W. Wandenbruwaene (Eds.). The role of constitutional courts in multilevel governance (pp. 105-130). Cambridge, United Kingdom: Intersentia.

Greenwood, J. (2011). Actors of the common interest: The Brussels offices of the regions. Journal of European Integration, 33(4), 437-451.

Gunlicks, A. (2003). The Länder and German federalism. Manchester, United Kingdom: Manchester University Press.

Hooghe, L., \& Marks, G. (2001). Multi-level governance and European integration. New York, NY: Rowman and Littlefield.

Hooghe, L., \& Marks, G. (2010). Types of multi-level governance. In H. Enderlein, S. Wälti \& M. Zürn (Eds.), Handbook on multi-level governance (pp. 1731). Cheltenham, United Kingdom: Edward Elgar.

Ipsen, H.-P. (1966). Als Bundesstaat in der Gemeinschaft [In the Community as a federal state]. In E. von Caemmerer, H.-J. Schlochauer \& E. Steindorff (Eds.), Probleme des Europäischen Recht. Festschrift für Walter Hallstein (pp. 248-265). Frankfurt am Main, Germany: Klostermann.

Mangiameli, S. (2006). The role of regional and local government in European governance. In H.-J. Blanke \& S. Mangiameli (Eds.), Governing Europe under a constitution (pp. 457-481). Berlin, Germany: Springer.

Marks, G. (1992). Structural policy in the European Community. In A. Sbragia (Ed.), Europolitics: Institutions and policymaking in the "new" European Community (pp. 191-224). Washington, DC: The Brookings Institution.

Marks, G., \& Hooghe, L. (2004). Contrasting visions of multi-level governance. In I. Bache \& M. Flinders (Eds.), Multi-level governance (pp. 15-30). Oxford, United Kingdom: Oxford University Press.

Matteucci, N. (2010 [1964]). Breve storia del costituzionalismo [A brief history of constitutionalism]. Brescia, Italy: Morcelliana. 
McIlwain, C. H. (1958 [1947]). Constitutionalism: Ancient \& modern. New York, NY: Great Seal Books.

Moore, C. (2008). A Europe of the regions vs. the regions in Europe: Reflections on regional engagement in Brussels. Regional \& Federal Studies, 18(5), 517 535.

Morbidelli, G. (2010). Lezioni di Diritto Pubblico Comparato [Lessons of Comparative Public Law]. Costituzioni e costituzionalismo. Bologna, Italy: Monduzzi.

Nettesheim, M. (2009). Die Integrationsverantwortung der Länder - Folgerungen aus dem Urteil des Bundesverfassungsgerichts vom 30. Juni 2009 ("Lissabon-Urteil") [The responsibility of the Länder for integration: Conclusions from the judgment of the Federal Constitutional Court of 30 June 2009 ("Lisbon-Verdict")] [Workshop paper]. Tübingen, Germany.

Nettesheim, M. (2012). Wo "endet" das Grundgesetz? - Verfassungsgebung als grenzüberschreitender Prozess [Where is the "end" of the Fundamental Law? - Constitution-making as a limit-crossing process]. Der Staat, 51(3), 313-355.

Nettesheim, M. ( 2014, March). Subsidiarität durch politische Koordination [Subsidiarity through political coordination]. Paper presented at the "Grenzen Europäischer Normgebung: EU-Kompetenzen und Europäische Grundrechte" Symposium, Frankfurt am Main, Germany.

Nolte, G. (2005). European and US constitutionalism: Comparing essential elements. In G. Nolte (Ed.), European and US constitutionalism (pp. 3-20). Cambridge, United Kingdom: Cambridge University Press.

Panara, C. (2010). In the name of cooperation: The external relations of the German länder and their participation in the EU decision-making. European Constitutional Law Review, 6(2), 59-83.

Panara, C. (2011). Germany: A cooperative solution to the challenge of the European integration. In C. Panara \& A. De Becker (Eds.), The role of the regions in EU governance (pp. 133-156). Berlin, Germany: Springer.

Panara, C. (2015). The sub-national dimension of the EU: A legal study of multilevel governance. Berlin, Germany: Springer.

Panara, C. (2016a). The enforceability of subsidiarity and the ethos of cooperative federalism: A comparative law perspective. European Public Law, 22(2), 305-332.

Panara, Carlo (2016b). The contribution of local and regional authorities to a "good" system of governance within the EU. Maastricht Journal of European and Comparative Law, 23(4), 611-639.

Panara, C., \& De Becker, A. (2011). Conclusion - The role of the regions in the European Union: The "regional blindness" of both the regions and the member states. In C. Panara \& A. De Becker (Eds.), The role of the regions in EU governance (pp. 297-346). Berlin, Germany: Springer.

Pernice, I. (2002). Multilevel constitutionalism in the European Union (WHI-Paper 5/02). Berlin, Germany: Walter Hallstein-Institut

Pernice, I. (2009). The treaty of Lisbon: Multilevel constitutionalism in action. Columbia Journal of European Law, 15(3), 349-407. 
Pernice, I. (2010). Verfassungsverbund [Compound of constitutions]. In C. Franzius (Ed.), Strukturfragen der Europäischen Union (pp. 102-118). BadenBaden, Germany: Nomos.

Peters, B. G., \& Pierre, J. (2004). Multi-level governance and democracy: A Faustian bargain? In I. Bache \& M. Flinders (Eds.), Multi-level governance (pp. 75-89). Oxford, United Kingdom: Oxford University Press.

Piattoni, S. (2009). Multi-level governance: A historical and conceptual analysis. Journal of European Integration, 31(2), 163-180.

Piattoni, S. (2010). The Theory of Multi-level Governance: Conceptual, empirical, and normative challenges. Oxford, United Kingdom: Oxford University Press.

Poiares Maduro, M. (2012). Three claims of constitutional pluralism. In M. Avbelj \& J. Komarek (Eds.), Constitutional pluralism in the European Union and beyond (pp. 67-84). Oxford, United Kingdom: Oxford University Press.

Popelier, P. (2011). Governance and better regulation: Dealing with the legitimacy paradox. European Public Law, 17(3), 455-466.

Popelier, P. (2014). Subnational multilevel constitutionalism. Perspectives on Federalism, 6(2), 1-23.

Popelier, P., Mazmanyan, A., \& Vandenbruwaene, W. (Eds.) (2013). The role of constitutional courts in multilevel governance. Cambridge, United Kingdom: Intersentia.

Popelier, P., \& Vandenbruwaene, W. (2014). The constitutional adulthood of multi-level governance. Maastricht Journal of European and Comparative Law, 21(2), 225-228.

Reposo, A. (2005). Profili dello Stato autonomico [Aspects of the autonomic state] (2nd ed.). Turin, Italy: Giappichelli.

Ricci, S. (2011). The Committee of the Regions and the challenge of European governance. In C. Panara \& A. De Becker (Eds.), The role of the regions in EU governance (pp. 109-129). Berlin, Germany: Springer.

Schmitter, P., \& Kim, S. (2005). The experience of European integration and the potential for Northeast Asian integration. East-West Center Working Papers, 10.

Schütze, R. (2009a). From dual to cooperative federalism: The changing structure of European law. Oxford, United Kingdom: Oxford University Press.

Schütze, R. (2009b). Subsidiarity after Lisbon: Reinforcing the safeguards of federalism? Cambridge Law Journal, 68(3), 525-536.

Schütze, R. (2012). European constitutional law. Cambridge, United Kingdom: University Press.

Simonato, A. (2016). Multilevel governance. Profili costituzionali. Il coordinamento tra Regioni, Stato e UE [Constitutional profiles. Coordination between regions, state, and the EU]. Padua, Italy: CLEUP.

Skoutaris, N. (2012). The role of sub-state entities in the EU decision-making processes: A comparative constitutional law approach. In E. Cloots, G. De Baere \& S. Sottiaux (Eds.), Federalism in the European Union (pp. 210-229). Oxford, United Kingdom: Hart Publishing. 
Smismans, S. (2004). Law, legitimacy, and European governance: Functional participation in social regulation. Oxford, United Kingdom: Oxford University Press.

Stein, M., \& Turkewitsch, L. (2008, May). The concept of multi-level governance in studies of federalism. Paper presented at the International Political Science Association (IPSA) International Conference, Montreal, Canada. Retrieved from http://paperroom.ipsa.org/papers/paper_4081.pdf

Stephenson, P. (2013). Twenty years of multi-level governance: Where does it come from? What is it? Where does it go? Journal of European Public Policy, 20(6), 817-837.

Streinz, R. (2012). Commentary to Art. 4 EUV. In R. Streinz (Ed.), EUV/AEUV (2nd ed.). Munich, Germany: Beck.

Thies, A. (2011). The locus standi of the regions before EU courts. In C. Panara and A. De Becker (Eds.), The role of the regions in EU governance (pp. 25-53). Berlin, Germany: Springer.

Toth, A. G. (1992). The principle of subsidiarity in the Maastricht Treaty. Common Market Law Review, 29(6), 1079-1105.

Toth, A.G. (1994). Is subsidiarity justiciable? European Law Review, 19(4), 268-285.

Vandenbruwaene, W. (2012). Multi-tiered political questions: The ECJ's mandate in enforcing subsidiarity. Legisprudence, 6(3), 321-346.

Vandenbruwaene, W. (2013). The judicial enforcement of subsidiarity. In P. Popelier, A. Mazmanyan \& W. Vandenbruwaene (Eds.), The role of constitutional courts in multilevel governance (pp. 131-164). Cambridge, United Kingdom: Intersentia.

Vandenbruwaene, W. (2014). Multi-level governance through a constitutional prism. Maastricht Journal of European and Comparative Law, 21(2), 229-242.

Van Nuffel, P. (2011). The protection of member states' regions through the subsidiarity principle. In C. Panara \& A. De Becker (Eds.), The role of the regions in EU governance (pp. 55-79). Berlin, Germany: Springer.

Vara Arribas, G. (2005). The changing dynamics of sub-state participation: The Commission's proposals for increasing regional and local involvement in European policy processes. Eipascope, 2, 19-25.

Villamena, S. (2011). State and regions vis-ã-vis European integration: The "long (and slow) march" of the Italian regional state. In C. Panara \& A. De Becker (Eds.), The role of the regions in EU governance (pp. 157-183). Berlin, Germany: Springer.

Volpi, M. (1995). Stato federale e stato regionale: due modelli a confronto [Federal state and regional state: A comparison of two models]. Quaderni Costituzionali, 15(3), 367-409.

von Bogdandy, A. (2009). Founding principles. In A. von Bogdandy \& J. Bast (Eds.), Principles of European constitutional law (2nd ed.) (pp. 11-54). Oxford, United Kingdom: Hart Publishing.

von Bogdandy, A., \& Schill, S. (July 2010). Commentary to Art. 4 EUV. In E. Grabitz, M. Hilf \& M. Nettesheim (Eds.). Das Recht der Europäischen Union. Vol. 1. Munich, Germany: Beck. 
Panara, C. (2016). Multi-Level Governance as a Constitutional Principle ...

HKJU-CCPA, 16(4), 705-741

Warleigh, A. (1999). The Committee of the Regions: Institutionalising multi-level governance? London, United Kingdom: Kogan Page.

Weatherill, S., \& Bernitz, U. (Eds.) (2005). The role of regions and sub-national actors in Europe. Oxford, United Kingdom: Hart Publishing.

Wessels, W. (1997). An ever closer fusion? A dynamic macropolitical view on integration processes. Journal of Common Market Studies, 35(2), 267-269.

Winter, S. C., \& May, P. J. (2001). Motivation for compliance with environmental regulations. Journal of Policy Analysis and Management, 20(4), 675-698.

Working Group I (2002) Working Group I of the European Convention on the Principle of Subsidiarity, 23 September 2002, CONV 286/02. Brussels, Belgium. 


\section{MULTI-LEVEL GOVERNANCE AS A CONSTITUTIONAL PRINCIPLE IN THE LEGAL SYSTEM OF THE EUROPEAN UNION}

\section{Summary}

This is a legal study of multi-level governance (MLG) in the EU. Earlier legal studies investigated the nature of MLG as a legal principle, suggesting that $M L G$ is a "procedural principle" or a "principle of coordination" of the action of governmental and non-governmental actors at various levels within the EU. However, the legal bases of MLG still need to be persuasively identified in EU primary law and in the constitutional laws of the member states, the nature of $M L G$ as a legal principle in the context of the EU requires more compelling evidence, the normative content of MLG needs a more accurate definition, and the practical legal consequences of MLG still need to be clearly determined, especially the application of MLG by Union and national judiciaries. This study looks at these aspects from a legal perspective. It argues that MLG envisages participatory solutions to constitutional problems linked to the position of local and regional authorities in the EU. MLG is normatively linked to the principles of local and regional autonomy and of subsidiarity. It operationalises these principles in the multi-level context of the EU by envisaging the participation of local and regional authorities in $E U$ decision-making processes and in the implementation of EU law and policy. This study identifies four functions of MLG as a constitutional principle in the EU legal system: (1) the epistemological function concerning the nature of the EU, (2) the de iure condendo function, (3) the behaviour-shaping function, and (4) the interpretation-shaping function. $M L G$ as a legal principle shall also guide the interpretation and application of the law by the courts, and particularly the Court of Justice of the EU, in relation to the enforcement of the principle of subsidiarity, the enforcement of participation rights of local and regional authorities, and the locus standi of local and regional authorities in direct challenges to $E U$ acts in Union courts.

Keywords: multi-level governance, local self-government, regional self-government, EU legal system 


\section{VIŠERAZINSKO UPRAVLJANJE KAO USTAVNO NAČELO U PRAVNOM SUSTAVU EUROPSKE UNIJE}

\section{Sažetak}

Rad se bavi temom višerazinskog upravljanja u Europskoj uniji s pravnog aspekta. Prijašnja istraživanja bavila su se višerazinskim upravljanjem kao pravnim načelom navodeći na zaključak da je riječ o proceduralnom načelu ili načelu koordinacije poteza koje povlače sudionici vladinog i nevladinog sektora na različitim razinama unutar EU-a. Ipak, primarno zakonodavstvo EU-a $i$ ustavna zakonodavstva država članica tek trebaju uvjerljivo prepoznati pravne temelje višserazinskog upravljanja. Ono kao pravno načelo u kontekstu EU-a zabtijeva uvjerljivije dokaze, njegov normativni sadržaj valja preciznije definirati, a i jasno odrediti konkretne pravne posljedice, posebice njegovu primjenu u sudstvu EU-a i nacionalnim sudstvima država članica. Ovaj se rad bavi tim pitanjima s pravnog gledišta te zastupa stav da višerazinsko upravljanje predvida participativna rješenja za ustavne probleme vezane uz položaj lokalnih $i$ regionalnib vlasti u EU. Ono je normativno povezano s načelom lokalne $i$ regionalne autonomije i načelom supsidijarnosti te se u višerazinskom kontekstu EU-a operacionalizira predvidanjem sudjelovanja lokalnib $i$ regionalnih vlasti $u$ procesima odlučivanja na razini EU-a, kao i u primjeni zakona i politika EU-a. Rad izdvaja četiri funkcije višerazinskog upravljanja kao ustavnoga načela u pravnom sustavu EU-a. To su: (1) epistemološka funkcija koja se bavi prirodom EU-a, (2) funkcija de iure condendo, (3) funkcija oblikovanja postupanja, i (4) funkcija oblikovanja tumačenja. Kao pravno načelo ono će takoder usmjeravati sudove, posebice Europski sud pravde pri tumačenju $i$ primjeni zakona koji se odnose na provođenje načela supsidijarnosti i prava na sudjelovanje lokalnih $i$ regionalnib vlasti, kao i na locus standi lokalnib $i$ regionalnih vlasti u izravnom sukobu sa zakonima EU-a u postupcima koji se vode pred sudovima EU-a.

Ključne riječi: višerazinsko upravljanje, lokalna samouprava, regionalna samouprava, pravni sustav EU-a 
